\title{
The Use of Photogrammetric Techniques in Documenting Cultural Heritage: The Example of Aksaray Selime Sultan Tomb
}

\author{
Ali Ulvi ${ }^{1, *}$, Murat Yakar², Abdurahman Yasin Yiğit ${ }^{1}$, Yunus Kaya ${ }^{3}$ \\ ${ }^{1}$ Department of Hadim Vocational School, Selcuk University, Turkey \\ ${ }^{2}$ Department of Geomatic Engineering, Faculty of Engineering, Mersin University, Turkey \\ ${ }^{3}$ Department of Geomatic Engineering, Faculty of Engineering, Harran University, Turkey
}

Copyright $\bigcirc 2019$ by authors, all rights reserved. Authors agree that this article remains permanently open access under the terms of the Creative Commons Attribution License 4.0 International License

\begin{abstract}
Forming 3 dimensional models of the existing historical buildings and objects has a great importance in terms of conserving historical works, sustaining our history, and being able to transfer them to the next generations. For catching the fine geometrical views and details and digitally modelling, it is important to identify a suitable method. It is necessary to digitally record, document, and conserve our cultural assets due to still ongoing wars, natural disasters, and climatic changes. The simplest way for permanently storing the original form and location of historical works with high quality views and details in digital media, forming base for the different projects, and making ready for use, if necessary, is to model the works in 3 dimensions. Beginning from the increase of importance to historical works, in parallelism with this, the importance and sorts of documentation also have begun to increase. Among the existing documentation methods, the method that is suitable to work in metric (via measurement), visual (photographing) and digital (computerized) media and appropriate in terms of time, space, and cost is photogrammetry. In forming and documenting 3 dimensional model of Selime Sultan Tomb located near Ihlara Valley, two different kinds of software of photogrammetric assessment were used.
\end{abstract}

Keywords Cultural Heritage, Historical Work Documentation, 3 Dimensional Model, Photogrammetry

\section{Introduction}

Every person is in connection with cultural heritage. Cultural heritages carry all traces of the life style and religious and social activities. Cultural heritage can consist of many things large and small e.g. buildings, towns, archeological remains, books, sculptures, clothes, equipment used, religious elements, and so on. When we carefully look at these given examples, it is seen that the people affect cultural heritage intentionally and unintentionally. Hence, human beings are affected by many historical works from the past and forms life style according to these works. The current communities, regenerating the new lifestyles in that form, will also affect the next generations via cultural heritage. Since this cycle will survive as long as human beings exist, cultural heritages will always serve making intersocietal connection (bridge)

Our country is a part of land, which has important attributes from cultural point of view and hosted a number of civilizations throughout history. Hence, on Anatolian lands that is the cradle of civilizations a number of cultural heritages take place. The documentation and conservation of the cultural assests incorporating thousands years of knowledge that belong to many eras and is necessary to be transferred to the next generations are of indispensable elements [1].

Just as the metric, written, and visual documentation is used as the main data in the existing situation of cultural heritage, identifying problems, and every kind of conservation studies regarding the solution of these problems, it is an important way of transferring cultural heritage to the next generations and introducing it to society [2].

Besides documenting cultural heritages and transferring them to the next generations, the way to be followed during documentation method is also important. As a result of documentation carried out by 3 dimensional model of a work, all details from the metric and visual point of view can be easily stored in digital media. The method to be preferred in the production of 3 dimensional model has to provide certain advantages to the user. In modelling objects covering small area, the method of Close range 
photogrammetry, one of the photogrammetric methods, is more suitable. In the cases, in which the method of Close Range photogrammetric remains inadequate, UAVs, the use of which increase together with the developing technology at the present days, largely provide easiness.

\section{Methods of Documenting Cultural Heritage}

Traditional Documentation Methods

- Written Documentation (Report)

- Photographic Documentation

- $\quad$ Graphical (with drawing) Documentation

Actual Documentation Methods

- $\quad$ LIDAR

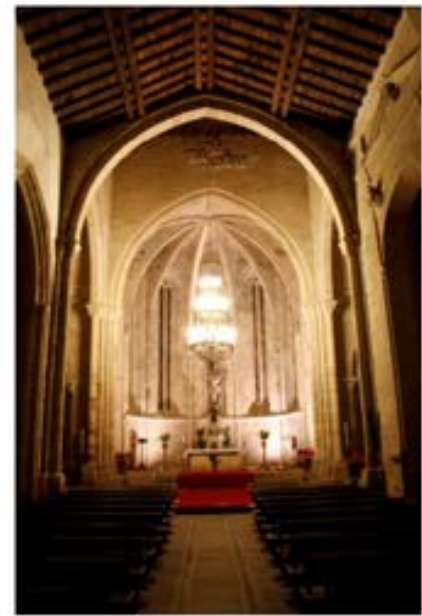

(A)

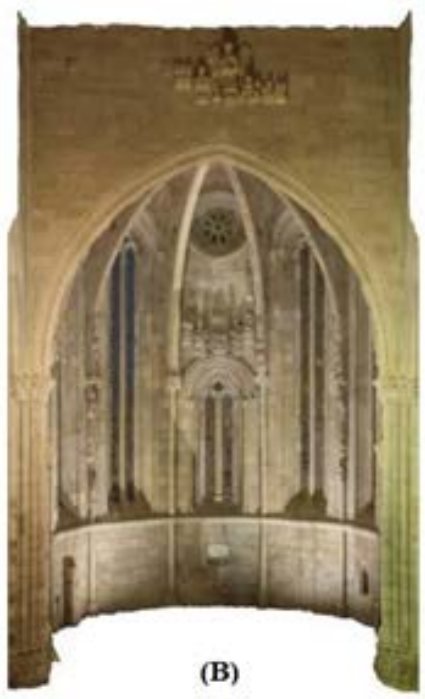

(B)
- $\quad$ Terrestrial Laser Scanning

- Close-Range Photogrammetry

- $\quad$ Filling in the Forms of Information Index

- Analyses/Archeo-metric studies

- Aerial Photogrammetry

- UAV Technology

Close-Range Photogrammetry: It is a technique enabling us to identify the position, shape, and dimension of object, using photographic information obtained by collecting the appropriate photographic image data by means of a digital camera from ground-centered different positions.

\subsection{Some Examples of Studies Carried out by Using Close-range Photogrammetry Method}

San Francisco Church -La Coruña/Spain [3].

Figure 1. (A) Interior of San Francisco Church, (B) and (C) 3D Model Obtained by Close Range Photogrammetry 
Saint Anne Church Model - Bačko Novo Selo/ Serbia [4].

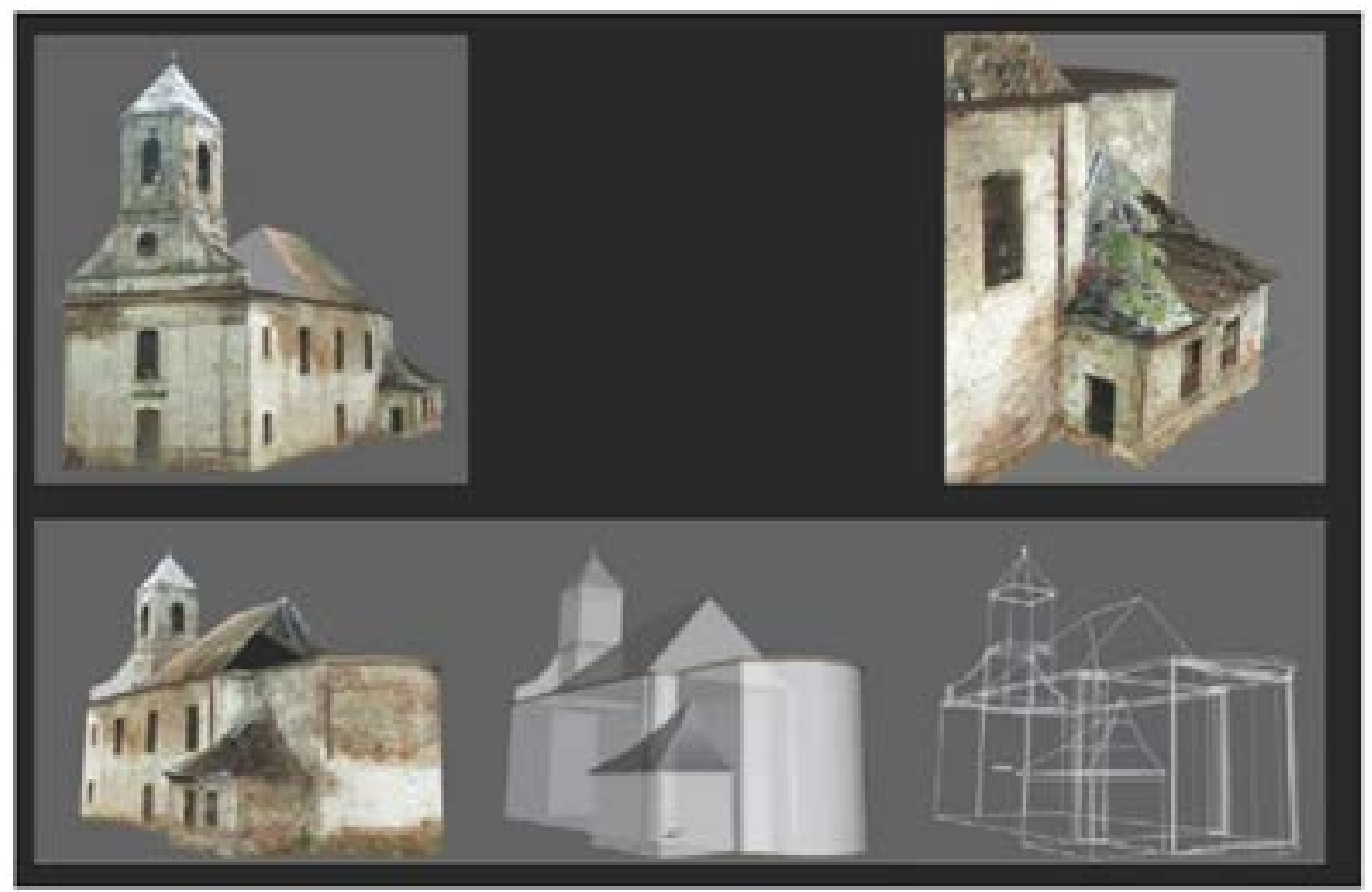

Figure 2. 3D Model of Saint Anne Church Obtained by Close Range Photogrammetry

Barutana Military Building Aresenal - NǐŠ/Serbia
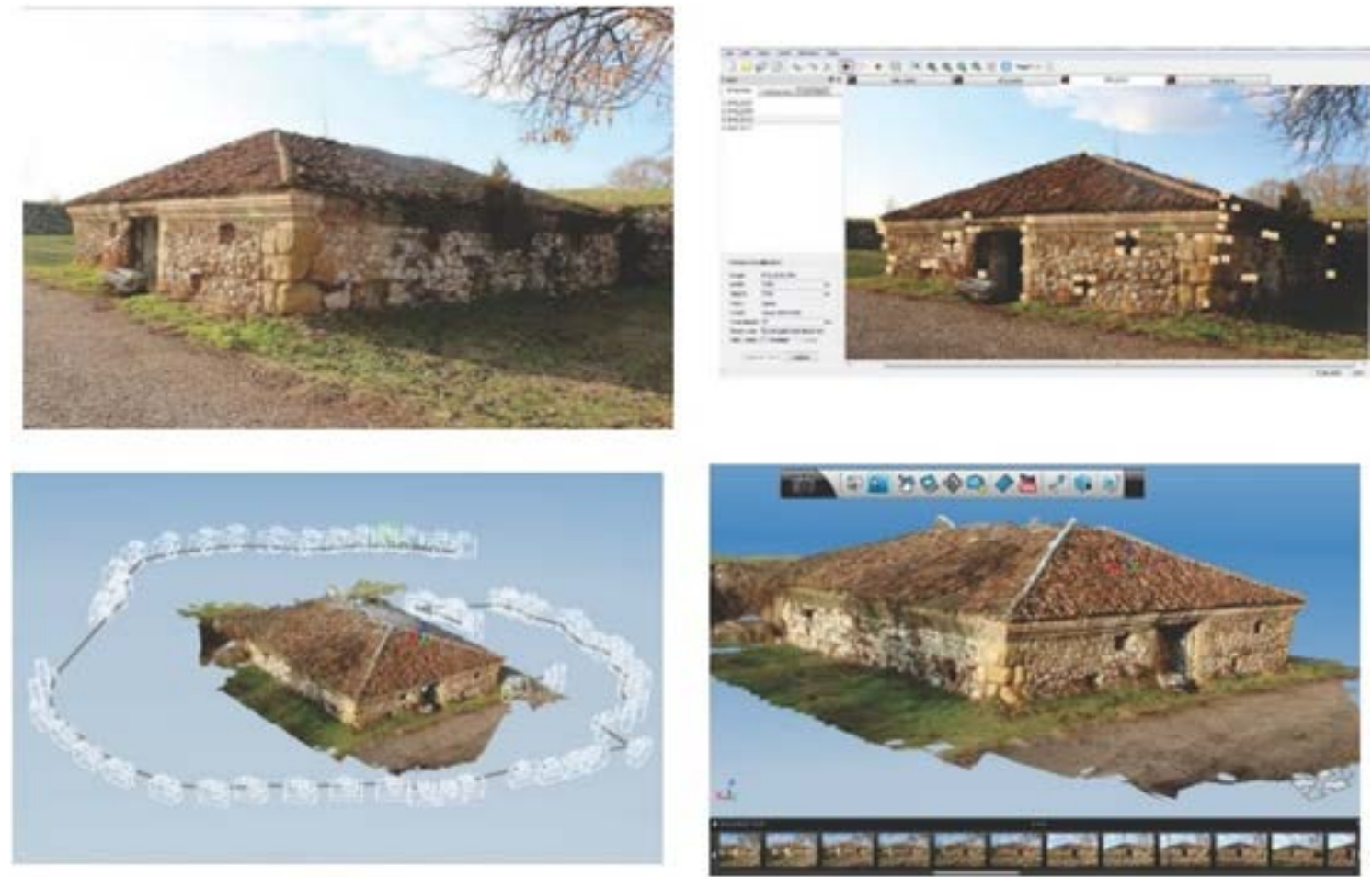

Figure 3. 3D Model of Saint Anne Church Obtained by Close Range Photogrammetry 
Building of Department of Civil Enginerring, Indian Technology Institute - Roorkee/India [6].
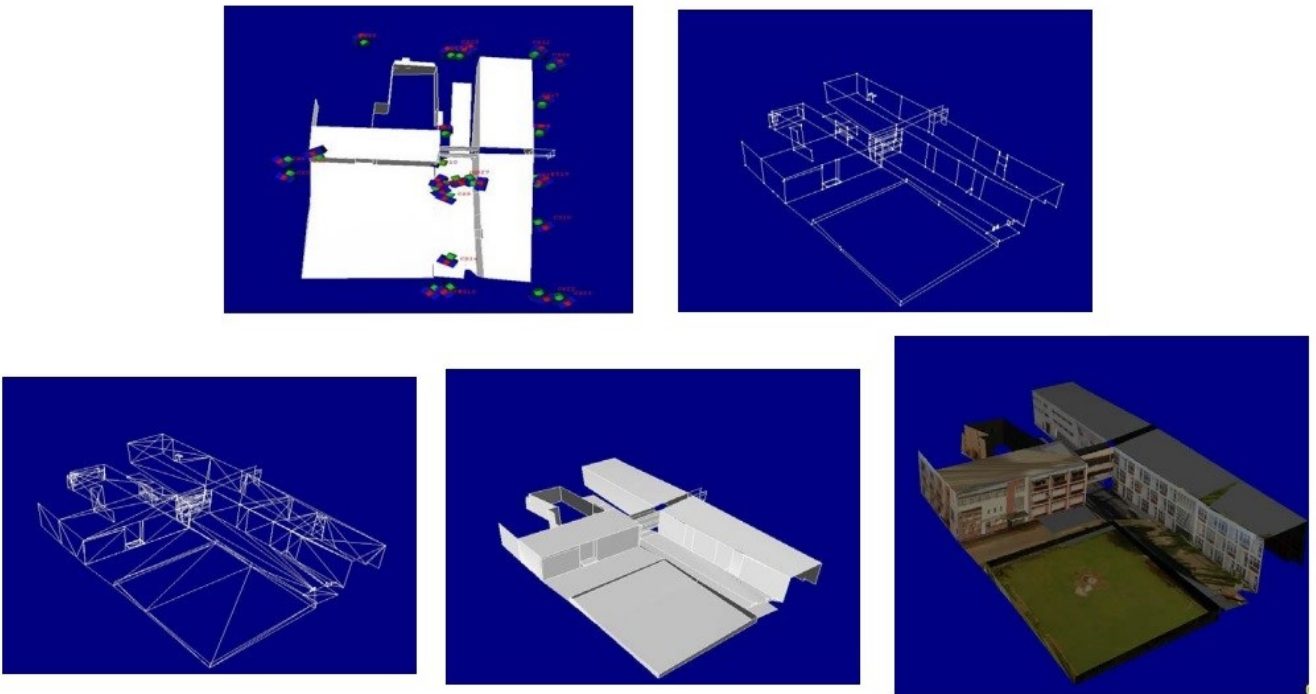

Figure 4. 3D Model of Building of Department of Civil Engineering, Indian Technology Institute Obtained by Close Range Photogrammetry Technique

Cambazlı Kilisesi (Cambazlı Church) Mersin/Turkey [7].
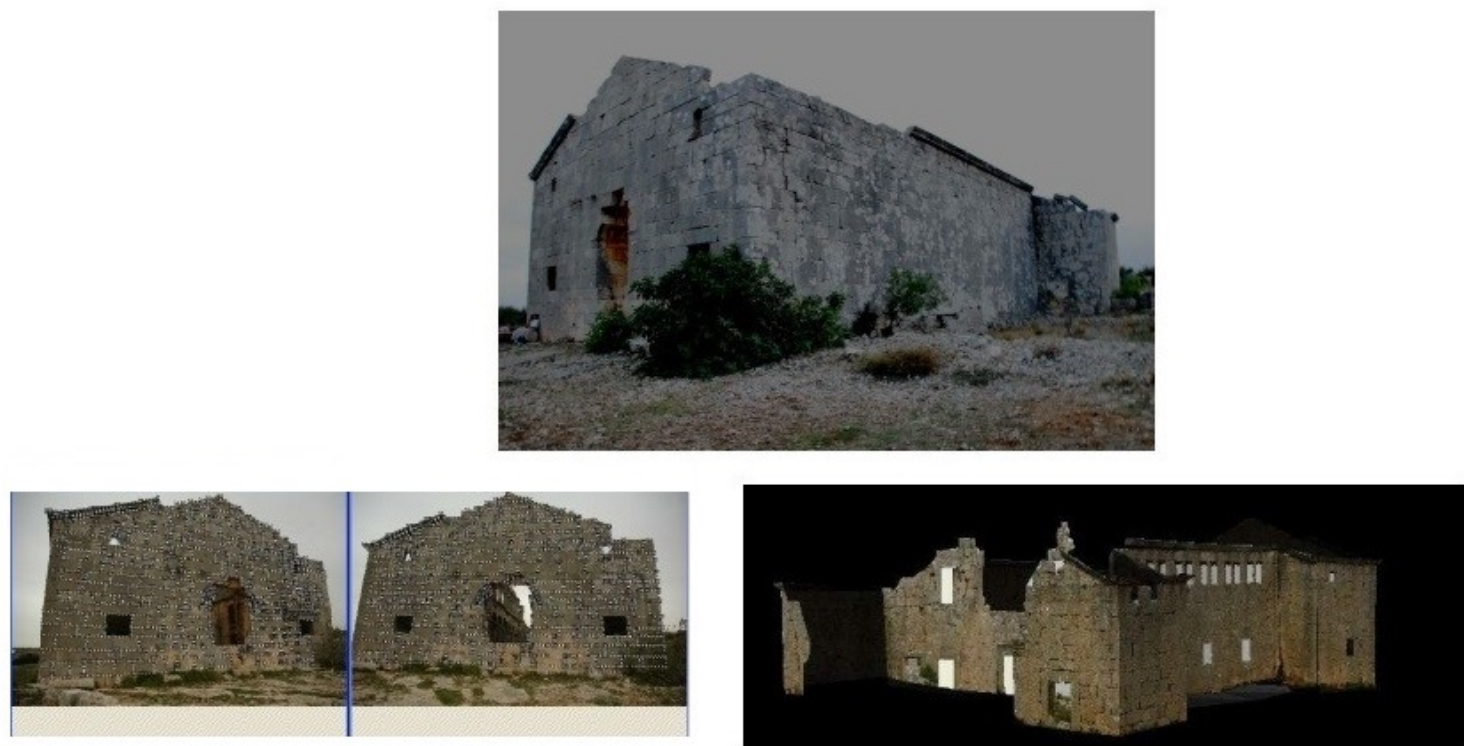

Figure 5. 3D Model of Saint Anne Church Obtained by Close Range Photogrammetry 


\section{Study Area}

Position of Tomb:. Selime Sultan Tomb is in Selime Village of Güzelyurt Township at the southeast of Aksaray

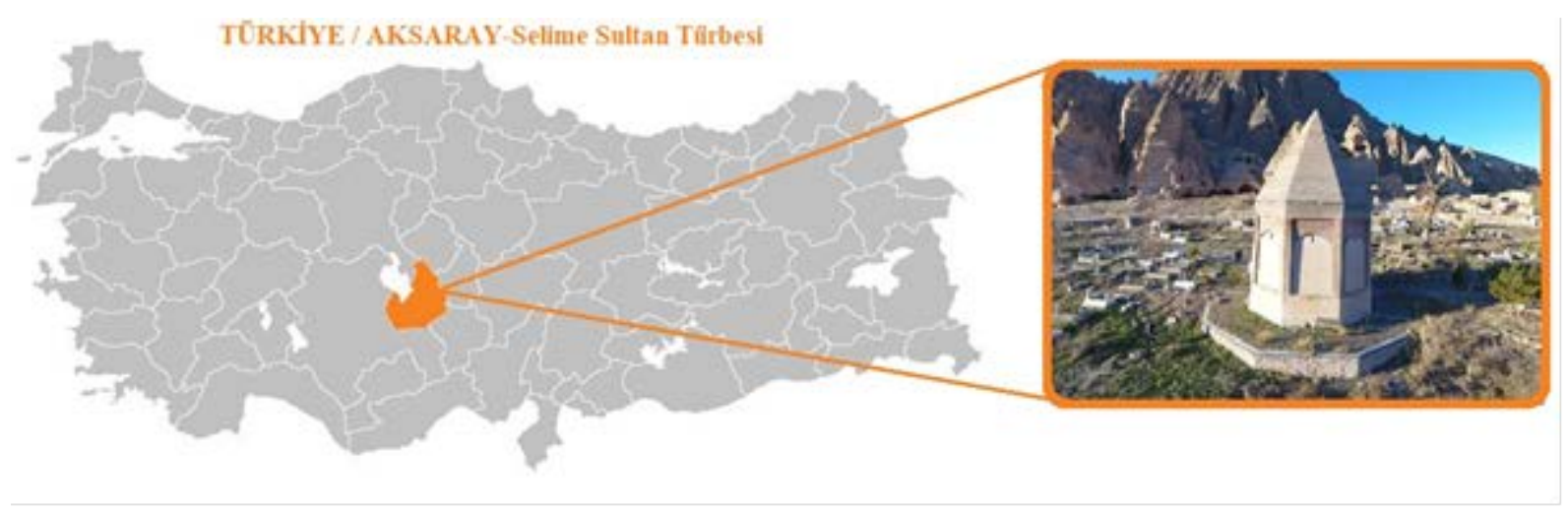

Figure 6. Position of Selime Sultan Tomb

Construction Date of the Tomb: Since there is no construction epitaph at the building, based on the plan and decorations, it is accepted that it was built in the first quarter of 13th Century.

State of Tomb: The serious cracks formed on the walls of the tomb. It was repaired by General Directorate of Waqfs in the years of 1975-1976. During this repair, stone coverings were renewed and brickworks were overhauled. Eliminating cracks, they were rebuilt by cone bricks.

Architecture of the Tomb: In construction of the tomb, stone and brick were used. The tomb, soaring on a stone pedestal with 8 edges and frame with 8 edges following it, is covered a cone that is a pyramid on it. The tomb is covered by cut stone to pedestal outside. The upper frame is covered with the bricks and its other edges are decorated by niches with blind sharp arches [8] except for north side, where there is entrance.

\section{Study Method}

\subsection{Field Study}

Field study was firstly realized by taking the coordinates of detail points that are sharp and remarkable or reflects the characteristic features of the object: Taking coordinates were made by means of total station, a classic measuring device.

Table 1. The main technical specifications of Topcon-Gpt-7003i [9]

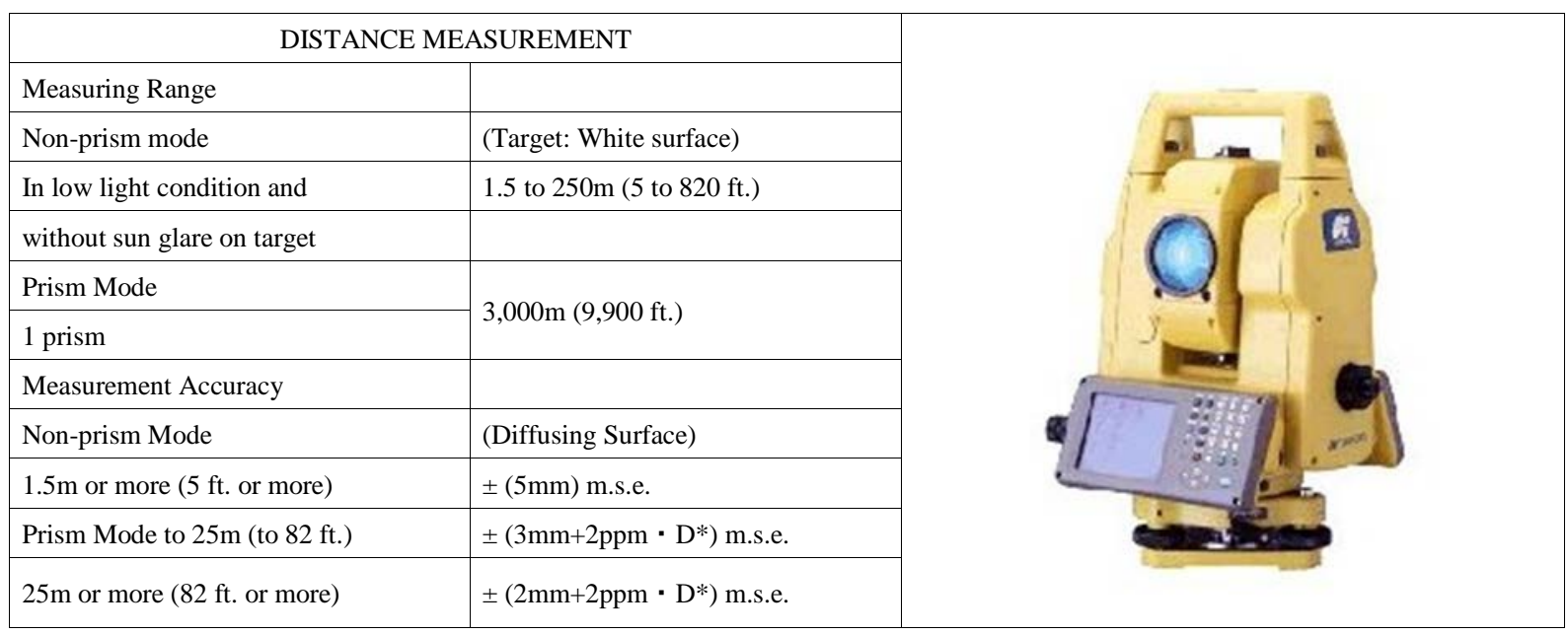




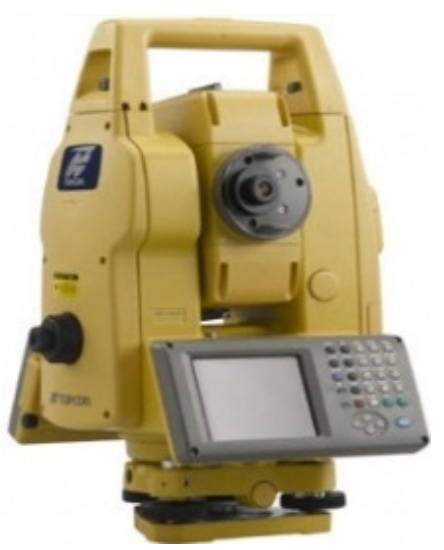

Figure 7. Topcon-Gpt-7003i Total Station

After measurement process, photographs were obtained by means of digital camera and UAV as overlapped. It was paid attention that the photographs taken from the ground by means of digital camera had to cover more details, while the photographs taken from air by means of UAV had to include the details remaining on the roof of tomb and broadly cover the study area.

Table 2. Canon EOS 100D Digital Camera and Its Technical Specifications [10]

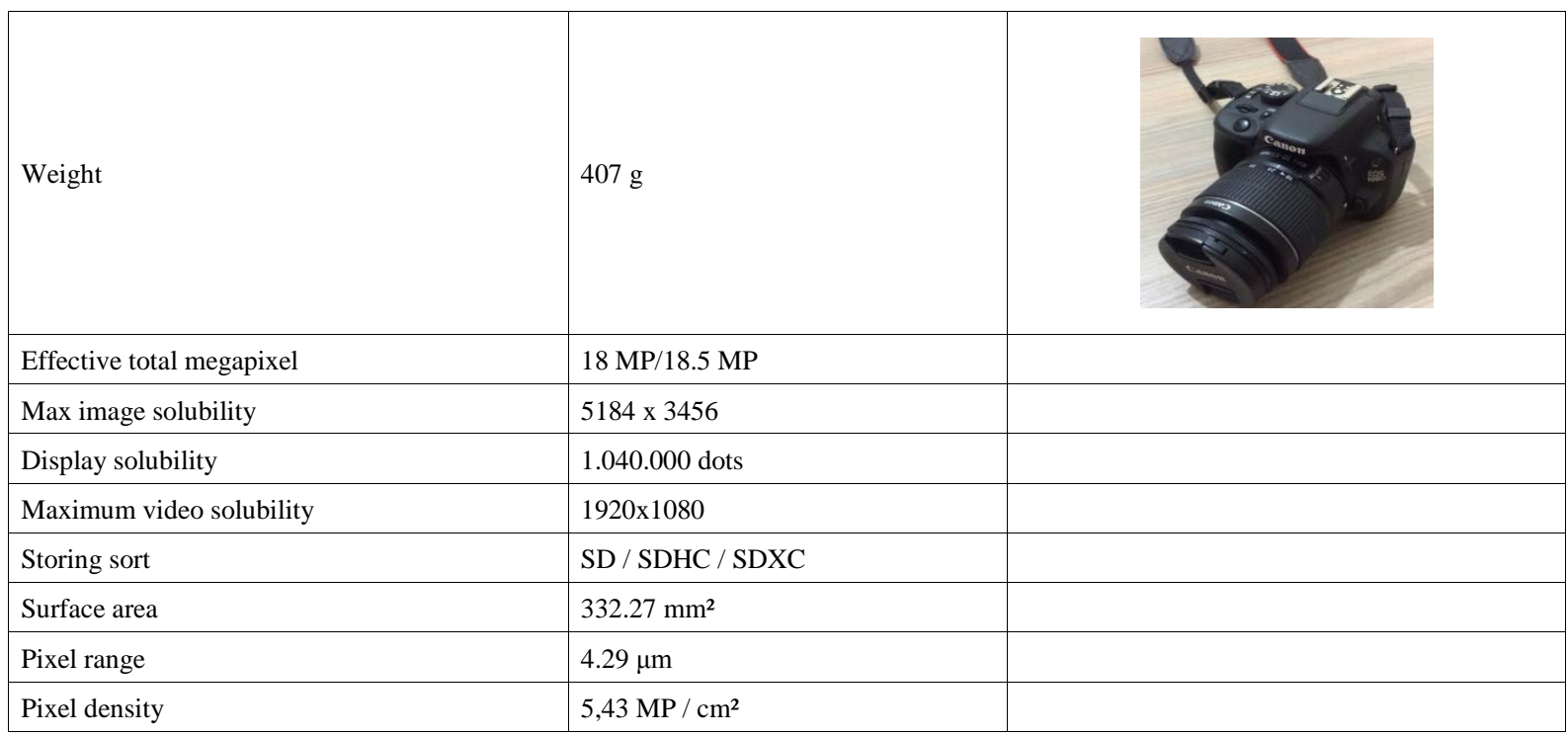

Table 3. Phantom 3 Professional UAV and Its Technical Specifications [11]

\begin{tabular}{|l|l|}
\hline & \\
\hline Phantom 3 Professional & \\
\hline Weight : $1280 \mathrm{~g}$ & \\
\hline Maximum Flight Time : Approx. 23 minutes Satellite Positioning Systems :GPS / GLONASS & \\
\hline Accuracy Range: Vertical : $\pm 0.1 \mathrm{~m}($ View Position $) \pm 0.5 \mathrm{~m}(\mathrm{GPS}$ Position $)$ & \\
\hline Horizontal : $\pm 0.3 \mathrm{~m}($ View Position $) \pm 1.5 \mathrm{~m}$ (GPS Position $)$ & \\
\hline Maximum Height 19685 feet $(6000 \mathrm{~m})$ & \\
\hline Camera megapixel $: 14.2 \mathrm{MP}$ & \\
\hline
\end{tabular}




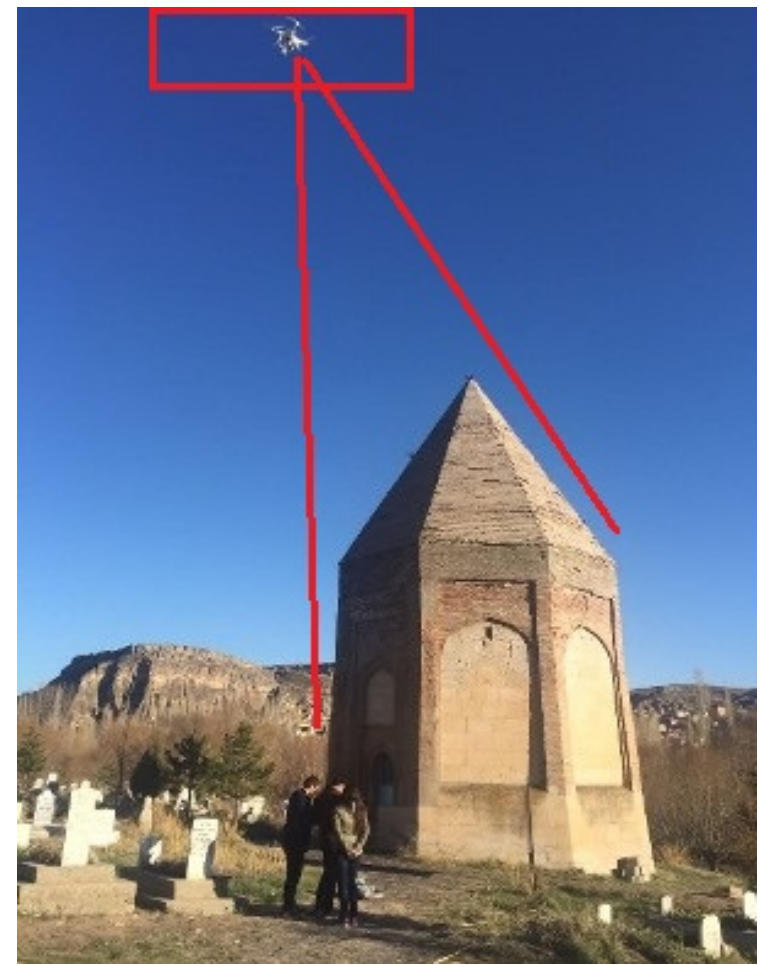

Figure 8. Photographing the Object by means of UAV
In the field study, after completing measurement and photographing process, it was proceeded to office study. In office study, two different software of photographic assessment were used. Firstly, the study was begun by means of drawing -based software. After controlling detail pints belonging to the object measured in the field, these points and photographs belonging to the object were transferred to 3 dimensional photographic assessment software. Firstly, the process of combining and aligning the photos was manually carried out. Through the photos aligned, making detailed drawings and process of getting surface through, 3 dimensional model of Selime Sultan Tomb was obtained. In the first software, after completing the documentation process, it was proceeded to the second software, which can produce 3 dimensional model by forming dense point cloud through the photographs. After the photographs and points were transferred to the software, detail points were placed in the photographs. Using dense point cloud belonging to the object, 3 dimensional high quality model and documentation process of Selime Sultan Tomb were completed Through 3 dimensional models obtained from both software, some points, which were manually measured in the field, were checked, and both software were compared to each other.

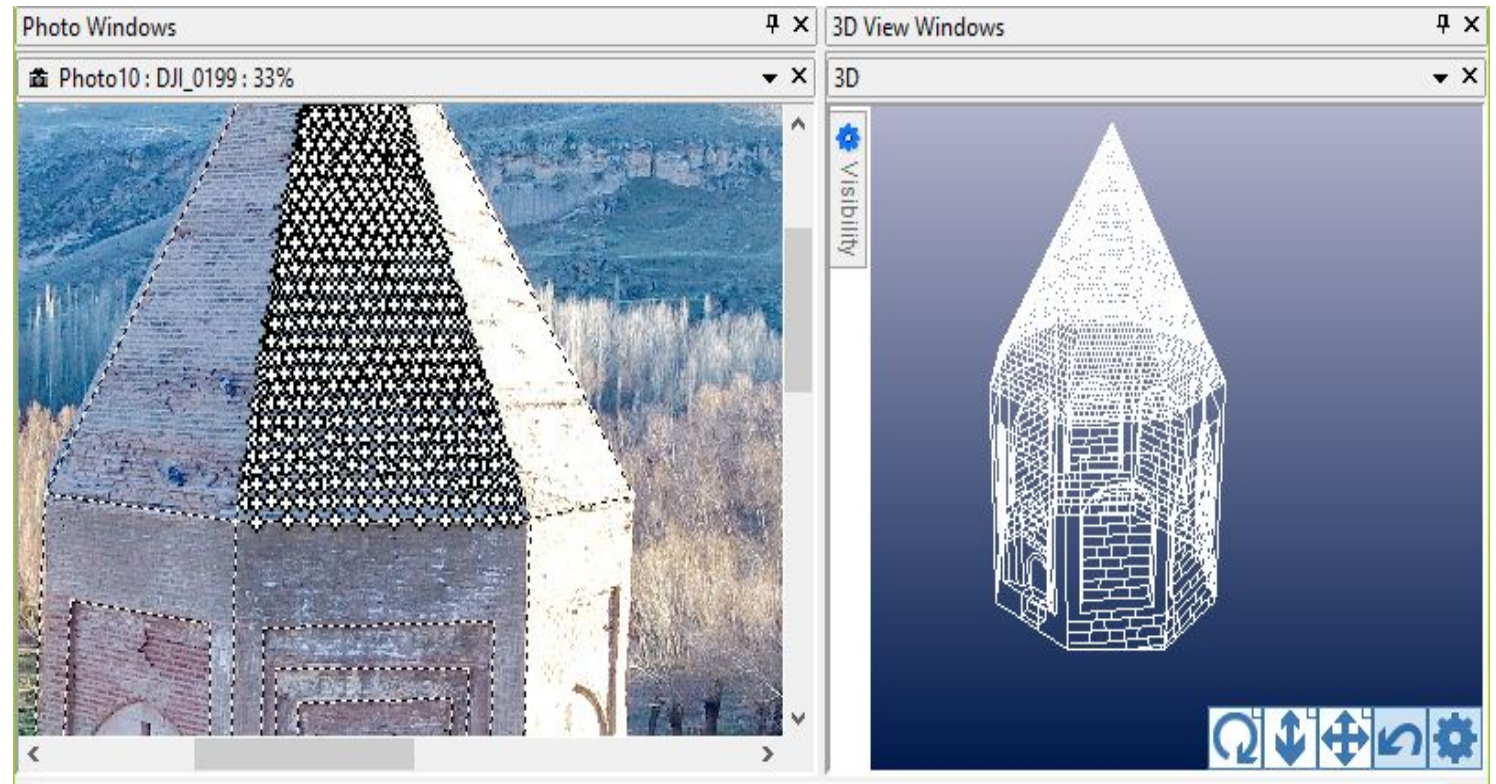

Figure 9. Detail Drawing of the Tomb 

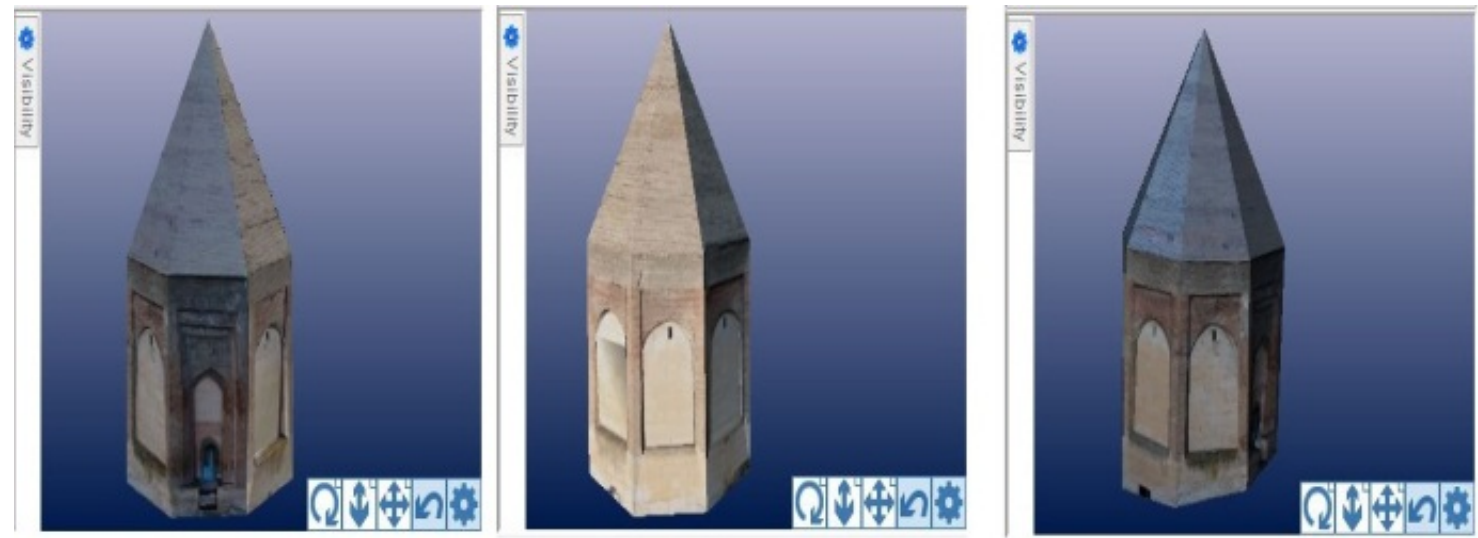

Figure 10. Surface -dressed 3 dimensional model of Selime Sultan Tomb

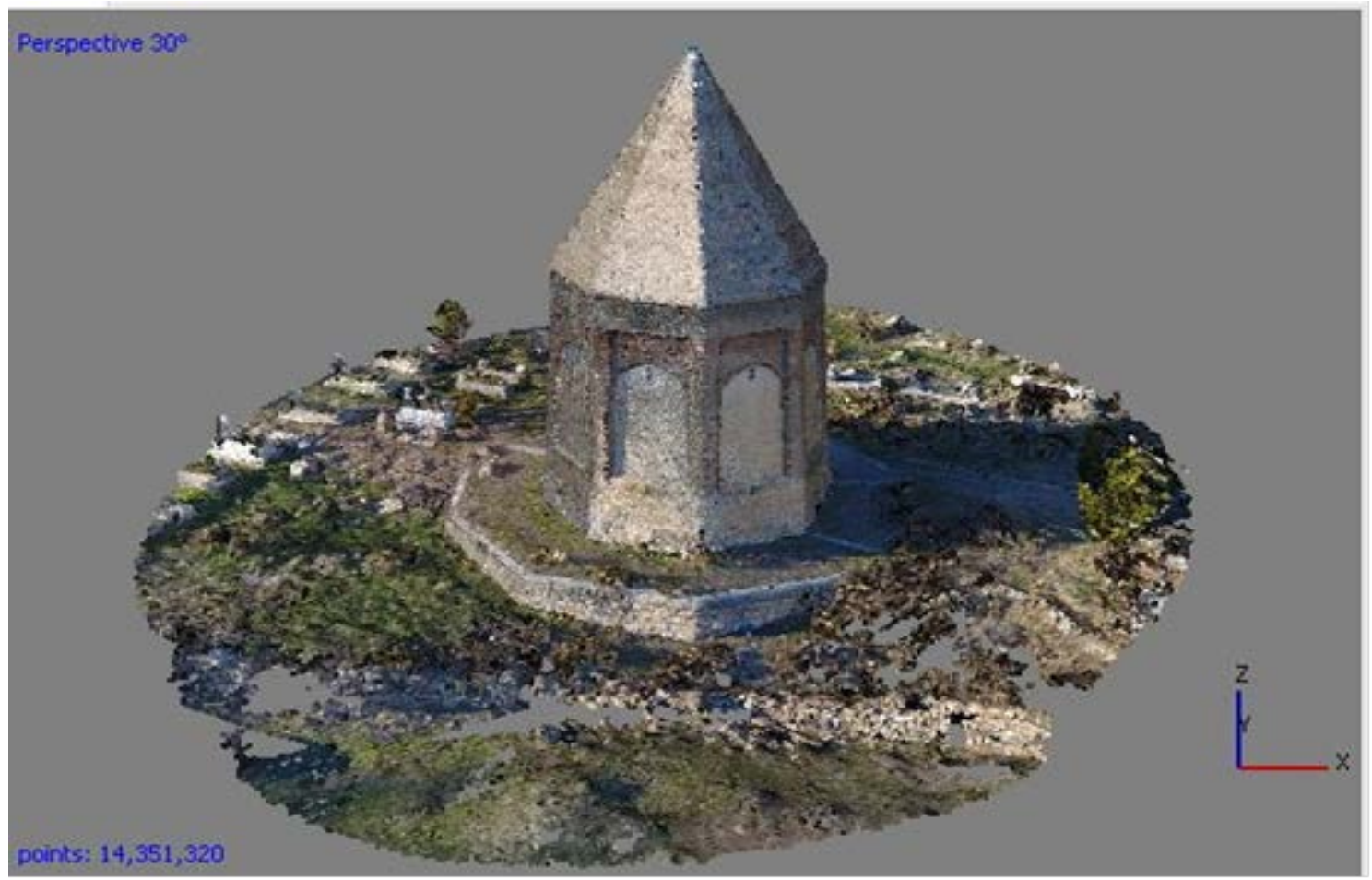

Figure 11. Dense Point Cloud of the Tomb ( 14.351 .320 points)

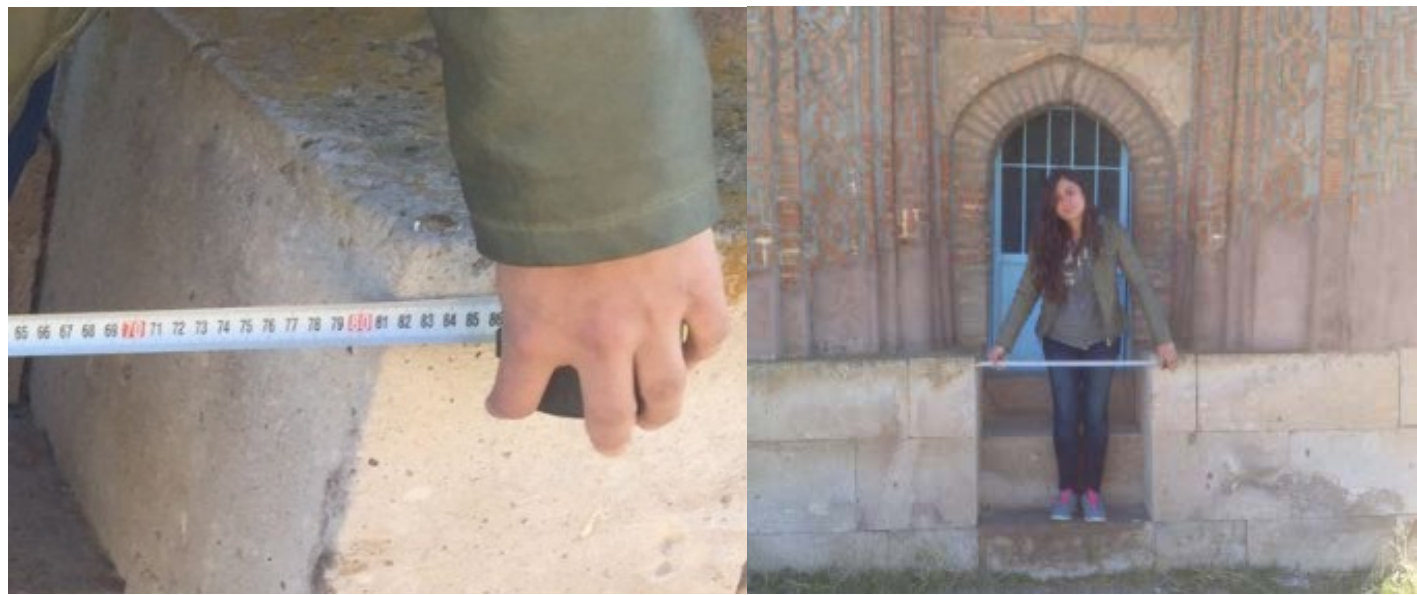

Figure 12. Control-purposed manual distance measurement $(82 \mathrm{~cm})$ 


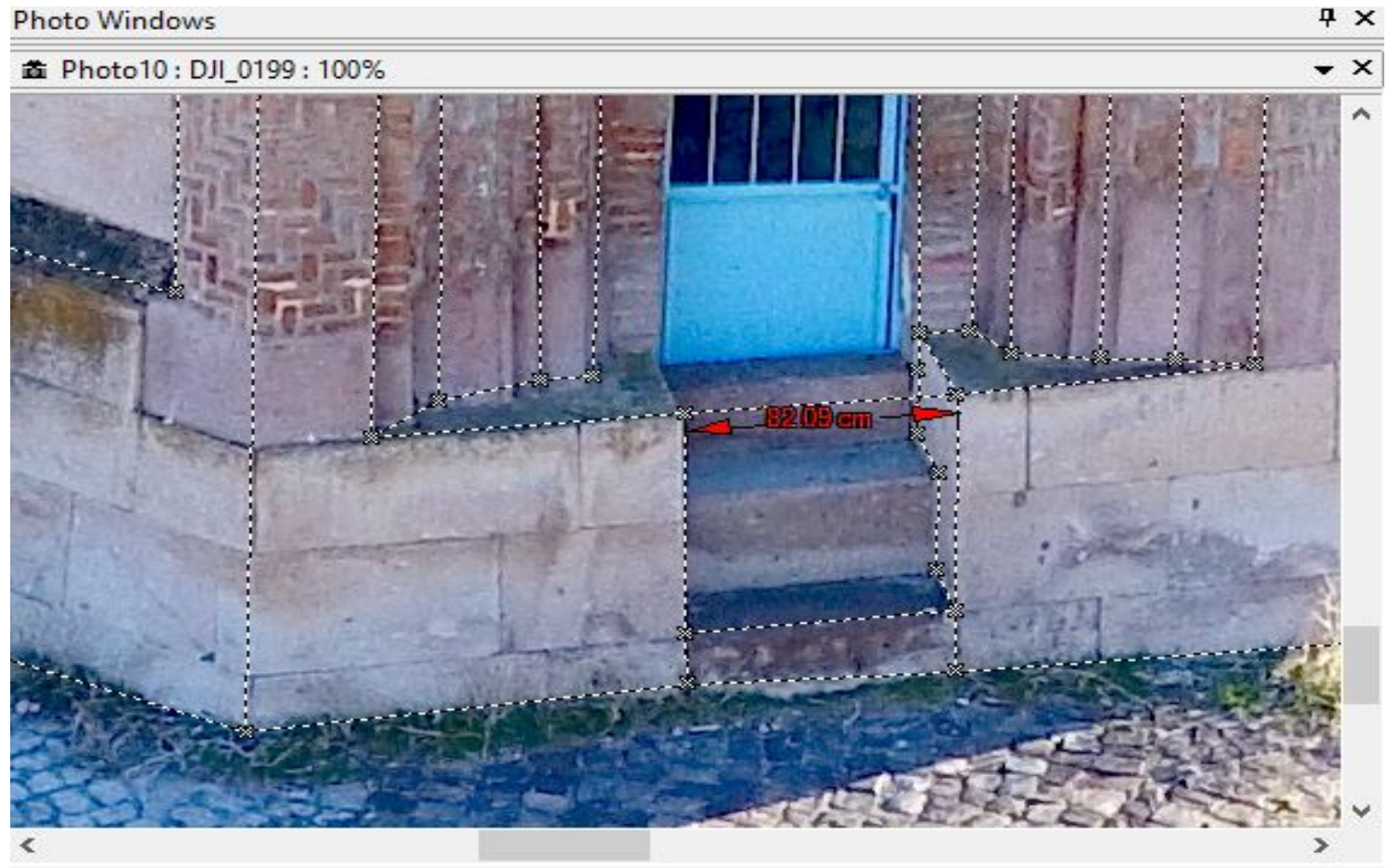

Figure 13. Measurement for Checking in drawing based software $(82,09 \mathrm{~cm})$

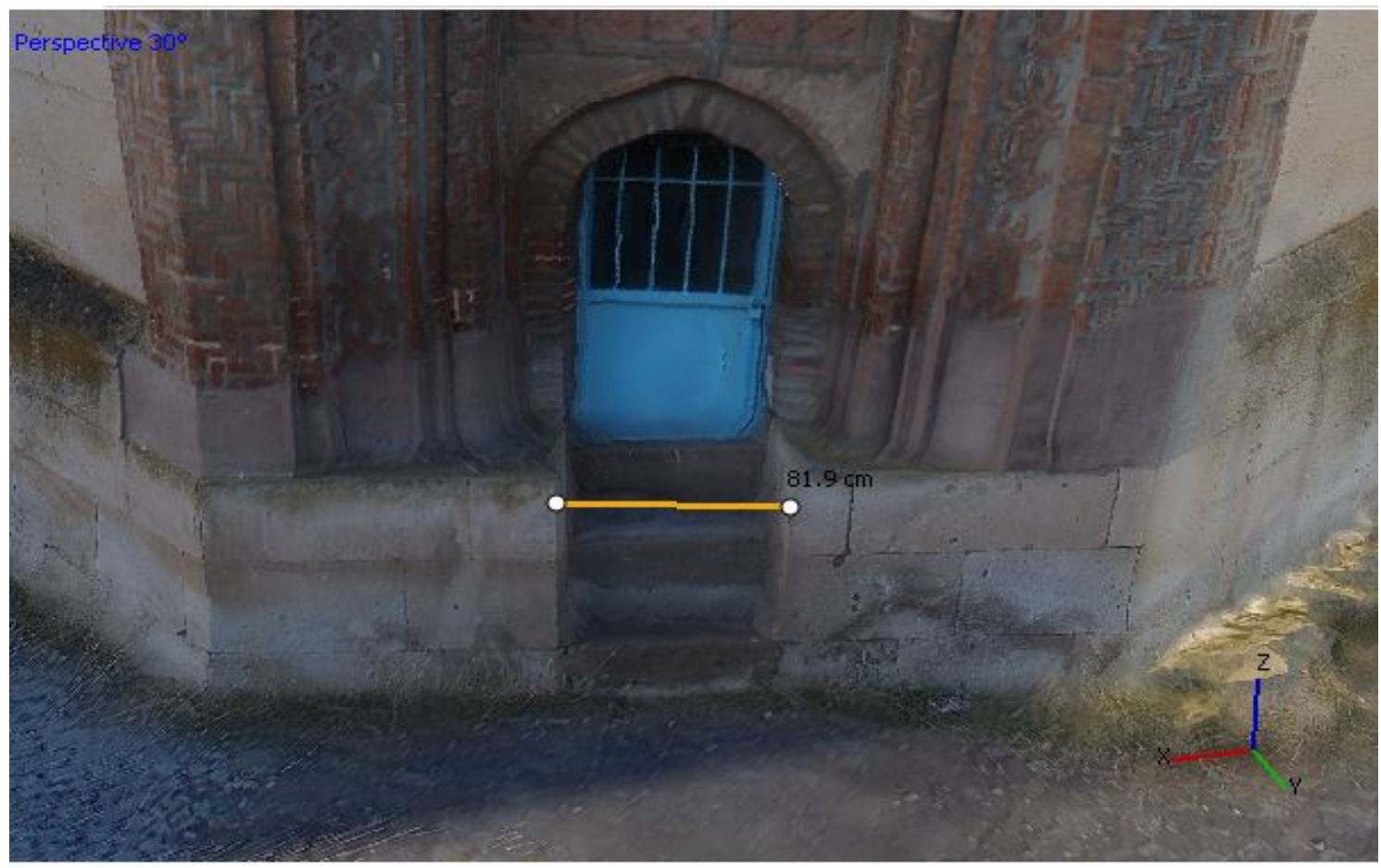

Figure 14. Measurement for Checking In Dense Point Cloud - Based Software $(81,9 \mathrm{Cm})$ 


\section{Conclusions}

Cultural heritage helps to build a bridge between the past, present, and future of a society. Conserving, documenting these historical bridges and transferring them to the next generations are not only important but also obligatory. This obligation also caused diversity in the method of documenting cultural heritage to increase. Especially in documenting historical works, 3 dimensional documentation method has advantages over the other documentation method from the metric, visual, and precision point of view. Topographic photogrammetry method is preferred in the various disciplines for many purposes. This method is preferred to the other methods from the metric, visual, and precision points of view as well as rapidity, cost, and accuracy.

In 3 dimensional documentation study of Selime Sultan Tomb, two different softwares were used and the differences between them were revealed. It was seen that the width of stair that is $82 \mathrm{~cm}$ turned out $82.09 \mathrm{~cm}$ in drawing-based software and $81.9 \mathrm{~cm}$ in point cloud based software. These results show us that we can also produce a high-precision model in both softwares.

\section{REFERENCES}

[1] Uslu, A., Polat, N., Toprak, A., \& Uysal, M. (2016). Kültürel Mirasın Fotogrametrik Yöntemle 3B Modellenmesi Örneği. Harita Teknolojileri Elektronik Dergisi, 8(2), 165-176.

[2] Yakar, M., Orhan, O., Ulvi, A., Yiğit, A.Y., \& Yüzer, M. (25-28 Mart 2015). Sahip Ata Külliyesi Rölöve Örneği. TMMOB Harita ve Kadastro Mühendisleri Odası, 15. Türkiye Harita Bilimsel ve Teknik Kurultayı. Ankara.

[3] Ramos, A. P., \& Prieto, G. R. (2015). 3D virtualization by close range photogrammetry indoor gothic church apses. the case study of church of San Francisco in Betanzos (La Coruña, Spain). International Archives of the Photogrammetry, Remote Sensing and Spatial Information Sciences - ISPRS Archives, 40(5W4), 201-206. https://doi.org/10.5194/isprsarchives-XL-5-W4-201-2015

[4] Stojaković, V. (2008). Terrestrial photogrammetry and application to modeling architectural objects. Facta Universitatis, 6(1), 113-125. https://doi.org/10.2298/FUA CE0801113S

[5] Pejić, P., Krasić, S., Krstić, H., Dragović, M., \& Akbiyik, Y. (2017). 3D virtual modelling of existing objects by terrestrial photogrammetric methods - case study of Barutana. Tehnicki Vjesnik - Technical Gazette, 24(Supplement 1), 233-239. https://doi.org/10.17559/TV20141018155354

[6] Pal Singh, S., Jain, K., \& Mandla, V. R. (2013). Virtual 3D Campus Modeling by Using Close Range Photogrammetry. American Journal of Civil Engineering and Architecture, 1(6), 200-205. https://doi.org/10.12691/ajcea-1-6-9

[7] Yakar, M., Yılmaz, H., Yıldız, F., Zeybek, M., Şentürk, H.,
\& Çelik, H. (11-15/05/2009). Silifke-Mersin Bölgesinde Roma Dönemi Eserlerinin 3-Boyutlu Modelleme Çalişmasi Ve Animasyonu. TMMOB Harita ve Kadastro Mühendisleri Odası 12. Türkiye Harita Bilimsel ve Teknik Kurultay1. Ankara.

[8] http://www.anadoluselcuklumimarisi.com/asyep/veri-tabani ?fid $=670$

[9] http://www.usasurveyingsupplies.com/index.php?route=

[10] https://www.digicamdb.com/specs/canon_eos-100d/

[11] https://www.dji.com/phantom-3-pro/info\#specs 